Haya: The Saudi Journal of Life Sciences

Abbreviated Key Title: Haya Saudi J Life Sci

ISSN 2415-623X (Print) |ISSN 2415-6221 (Online)

Scholars Middle East Publishers, Dubai, United Arab Emirates

Journal homepage: https://saudijournals.com

Original Research Article

\title{
Congenital Malformation among Children with Cerebral Palsy, And Gender Differences in EI- ALBYDA Hospital in LIBYA
}

Kawakeb. A. Saad ${ }^{1 *}$ and Mabsutah. O. Saeid ${ }^{2}$

${ }^{1}$ Department of Zoology, Faculty of Sciences, Umar Al Mukhtar University, ALBYDA, LIBYA)

${ }^{2}$ Department of Neurology in ALTHOURA Hospital

DOI: $\underline{10.36348 / \text { sjls.2021.v06i01.001 }}$

| Received: 14.12.2020 | Accepted: 24.12.2020 | Published: 08.01.2021

*Corresponding author: Kawakeb. A. Saad

\section{Abstract}

Cerebral palsy (CP) is a major neurodevelopmental disorder, presently estimated to affect approximately 1 in 500 children. As a clinical diagnosis, the etiology of the syndrome varies and is often unknown. The objective of this study is to determine the pattern and the contributing factors of CP among Libyans children. This was a descriptive hospital-based study conducted over a period of six years in ALBYDA Central Hospital - LIBYA. One hundred and eight patients of CP were enrolled, of whom $70(65 \%)$ were males and $38(35 \%)$ were females. Spastic quadriplegic CP was the most common type and epilepsy was the most problem associated with $\mathrm{CP}$. Birth asphyxia, prematurity neonatal meningitis, kernicterus and brain malformation were the main contributing factors.

Keywords: Cerebral Palsy, sapstic cerebral palsy.

Copyright (C) 2021 The Author(s): This is an open-access article distributed under the terms of the Creative Commons Attribution 4.0 International License (CC BY-NC 4.0) which permits unrestricted use, distribution, and reproduction in any medium for non-commercial use provided the original author and source are credited.

\section{INTRODUCTION}

Cerebral palsy first described by William little in the $1840 \mathrm{~s}$ as a is a common developmental disability resulting from a non-progressive insult to the developing brain $[1,2]$.The most important risk factor seems to be prematurity and low birth weight with risk of $\mathrm{CP}$ increasing with decreasing gestational age and birth weight $[3,4]$.

The worldwide incidence of cerebral palsy ranges between 2 to 2.5 in 1,000 live births and is the most common neurological congenital disorder [5]. Cerebral palsy could be classified to monoplegia, hemiplegia, diplegia and quadriplegia; monoplegia and triplegia are relatively rare. Diplegia is the commonest form of CP $(30 \%-40 \%)$, hemiplegiae is $(20 \%-30 \%)$, and quadriplegia accounting for $(10 \%-15 \%)$. Study in India after examination of 1000 cases of $\mathrm{CP}$ found that spastic quadriplegia constituted $61 \%$ of cases followed by diplegia $22 \% .13$ [6].

The child with cerebral palsy has an malformed functioning CNS. The problem is stated in several ways, all of which are related with the primary problem [7].Common problems associated with $\mathrm{CP}$ include mental retardation, communicative and behavior disturbances. Seizures, feeding difficulties, visual and auditory disturbances are also seen with increasing frequency [8]. CP may cause a variety of associated complications, such as, feeding problems, hearing and visual anomalies, respiratory system infections, epilepsy, and mental and talkative losses in children [9]. Evidence to date suggests that, similar to other major neurodevelopmental disorders, duplications or deletions of portions of a chromosome (genomic copy number variants may explain $\mathrm{CP}$ in about $10 \%$ to $20 \%$ of cases $[10,11]$.

This study aimed to find the risk factors of cerebral palsy among patients admitted in neurological department in AL-HTOURA hospital in El-BIYDA city, and, to study the complications and birth defects of cerebral palsy among these patients.

\section{MATERIALS AND METHODS}

The current study a descriptive study based on hospital records of neurology department in ALHTOURA hospital in El-BIYDA city north LIBYA, 108 patients who admitted with diagnosis of cerebral palsy by consultant pediatricians or neurologists in period from 10/10/2011 until 10/5/2017. Risk factors of cerebral palsy such as birth weight, mode of delivery, and other variables such as complications were assets. 
Data entered into MS Excel sheet, analyzed by using chi square test, $\mathrm{P}$ value less than 0.05 considered significant. Data presented through frequency tables.

\section{RESULTS}

Among 108 children with CP, 38(35\%) were females, and $70(65 \%)$ were males, giving a male to female ratio of 1.8:1. As showed in Table, 1, Chi-square test indicted there is significant differences between male and female.

Table-1: Distribution of CP patients according to gender

\begin{tabular}{|c|c|}
\hline Gender & Number (\%) \\
\hline Male & $\mathbf{7 0} \mathbf{( 6 5 \% )}$ \\
\hline Female & $\mathbf{3 8} \mathbf{( 3 5 \% )}$ \\
\hline Chi-square test & $\mathbf{0 . 0 0 2 0 7 5 5 6 3}$ \\
\hline Statistical Significant at 0.05 level & Significant \\
\hline
\end{tabular}

The Children were ranging in age from 8 months to 17 years .Table 2 shows age and sex distribution.

Table-2: Distribution of CP patients according to age

\begin{tabular}{|c|c|c|c|}
\hline \multirow[t]{2}{*}{ Age in year } & \multicolumn{2}{|c|}{ Gender } & \multirow{2}{*}{$\begin{array}{l}\text { Total } \\
\text { No }(\%)\end{array}$} \\
\hline & Male & Female & \\
\hline Under 1 year & 1 & $\mathbf{0}$ & $1(0.931 \%)$ \\
\hline $1-5$ year & 27 & 13 & $45(41.66 \%)$ \\
\hline 6-10 year & 26 & 20 & $49(42.61 \%)$ \\
\hline Up to 10 year & 8 & 8 & $16(14.81 \%)$ \\
\hline Chi-square test & \multicolumn{3}{|c|}{0.00076931} \\
\hline Statistical Significant at 0.05 level & \multicolumn{3}{|c|}{ Significant $*$} \\
\hline
\end{tabular}

Most of patient delivered by vaginal delivery $86(79.62 \%)$ and $22(20.37)$ case delivered by Caesarean. There were $18(16.63 \%)$ cases preterm birth and most of cases $90(83.37 \%)$ were full term. Chisquare test showed no significant difference found with regard to type of delivery as showed in table (2).

Table-3: Distribution of CP patients according to type of delivery

\begin{tabular}{|c|c|c|c|}
\hline \multirow{2}{*}{ Gestational } & \multicolumn{2}{|c|}{ Mod of delivery } & \multirow{2}{*}{ Total } \\
\cline { 2 - 3 } & Normal & Caesarean & \\
\hline Term & $(70) 64.85 \%$ & $(20) 18.52 \%$ & 90 \\
\hline Preterm & $(16) 14.81 \%$ & $(2) 1.85 \%$ & 18 \\
\hline Total & $(86) 79.62 \%$ & $(22) 20.37 \%$ & 108 \\
\hline Chi-square test & \multicolumn{3}{|c|}{0.285304145} \\
\hline Statistical Significant at 0.05 level & \multicolumn{3}{|c|}{ significant } \\
\hline
\end{tabular}

Table 3 shoes around $94(86.11 \%$ ) cases their birth weight between $2.5-4.5 \mathrm{~kg}$, less than $2.5 \mathrm{Kg}$ were $14(13.89 \%)$ child.

Table-4: Distribution of CP patients according to Birth weight

\begin{tabular}{|c|c|c|c|}
\hline Birth weight & Male No & Female No & Total No (\%) \\
\hline Less than 2.5 g & 11 & 3 & $14(13.89 \%)$ \\
\hline Normal weight (2.5- 4.5) g & 57 & 37 & $94(86.11 \%)$ \\
\hline Total & 68 & 40 & 108 \\
\hline Chi-square test & \multicolumn{3}{|c|}{0.194866} \\
\hline Statistical Significant at 0.05 level & \multicolumn{3}{|c|}{ Not sificant } \\
\hline
\end{tabular}

That the most cases $(86=79.63 \%)$ belonged to the hypertonic-spastic type, being represented by qdriplegia being the most common $(55.56 \%)$, diplegia (19.44), and hemiplegia was (4.63), hypotonic type was
$(11.11 \%)$ Only $10 \quad(9.26 \%)$ cases were ataxia. Meanwhile, no significant difference was found with regard to gender $(\mathrm{p}>0.05)$. (as seen in Table 5). 
Table-5: Distribution of CP patients according to type of CP

\begin{tabular}{|c|c|c|c|}
\hline Types of CP & $\begin{array}{c}\text { Male } \\
\mathbf{N}(\%)\end{array}$ & $\begin{array}{c}\text { Female } \\
\mathbf{N}(\%)\end{array}$ & Total No(\%) \\
\hline Hypertonic spastic type & $37(43.26)$ & $23(21.30)$ & $60(55.56 \%)$ \\
\hline Quadriplegia & $12(11.11)$ & $9(8.33)$ & $21(19.44 \%)$ \\
\hline Diplegia & $3(2.78)$ & $2(1.85)$ & $5(4.63 \%)$ \\
\hline Hemiplegia & $10(9.26)$ & $0(0)$ & $10(9.26 \%)$ \\
\hline Ataxia & $8(7.41)$ & $4(3.70)$ & $12(11.11 \%)$ \\
\hline Hypotonic & $70(64.81)$ & $38(35.19)$ & 108 \\
\hline Total & \multicolumn{3}{|c|}{0.177823278} \\
\hline Chi-square test & \multicolumn{3}{|c}{ sotignificant } \\
\hline Statistical Significant at 0.05 level & \multicolumn{3}{|c}{} \\
\hline
\end{tabular}

The leading causes of cerebral palsy were birth asphyxia $(60=55.56 \%)$, prematurity $(18=16.67 \%)$, neonatal meningitis $(9=8.34 \%)$, kernicterus $(6=$ $5.56 \%)$. Brain mal formations, head defects $(9=8.34 \%)$
, neonatal jaundice and congenital infections, these conditions accounted for $(6=5.54 \%)$ all cases of cerebral palsy as shown in (table 6).

Table-6: Distribution of risk factors for CP

\begin{tabular}{|c|c|c|c|}
\hline Causes of cerebral palsy & $\begin{array}{c}\text { Numbers } \\
\text { Male }\end{array}$ & Numbers Female & (No) / \% \\
\hline Birth asphyxia & 37 & 23 & $(60) / 55.56 \%$ \\
\hline Prematurity & 15 & 3 & $(18) / 16.67 \%$ \\
\hline Neonatal meningitis & 7 & 2 & $(9) / 8.34 \%$ \\
\hline Kernicterus & 3 & 3 & $(6) / 5.56 \%$ \\
\hline Brain malformation & 3 & 2 & $(5) / 4.63 \%$ \\
\hline Head defects & 4 & 0 & $(4) / 3.70 \%$ \\
\hline Neonatal jaundice & 3 & 0 & $(3) / 2.76 \%$ \\
\hline Congenital infection & 1 & 3 & $(3) / 2.78 \%$ \\
\hline Chi-square test & \multicolumn{3}{|c|}{0.227366622} \\
\hline Statistical Significant at 0.05 level & \multicolumn{3}{|c|}{} \\
\hline
\end{tabular}

Complications associated with $\mathrm{CP}$ were presented in Table 7, epilepsy was found in 51 children $(47.22 \%)$, movement problems was represented in
33(30.55) of the children. Mental retardation was prominent in 14 children $(12.96 \%)$ and 12 (11.11) with visual impairment.

Table- 7: Distribution of Complication associated with CP

\begin{tabular}{|c|c|}
\hline Complication associated with CP & (No) / \% \\
\hline Epilepsy & $(51) 47.22 \%$ \\
\hline Movement problems & $(33) 30.55 \%$ \\
\hline Mental Retardation & $(64) 12.96 \%$ \\
\hline Visual problems & $(12) 11.11 \%$ \\
\hline Speech problems & $(11) 10.19 \%$ \\
\hline Microcephaly & $(11) 10.19 \%$ \\
\hline Hearing problems & $(1) 0.93 \%$ \\
\hline Chi-square test & 0.738664101 \\
\hline Statistical Significant at 0.05 level & Not significant \\
\hline
\end{tabular}

\section{DISCUSSION}

Defects in brain development contribute to long-term non progressive disorder of movement and posture, called cerebral paralysis, the study analyzed 108 children with cerebral palsy, male appear to be at higher risk of CP than females with a ratio of 1.8:1,

Six differences were confirmed in many previous studies [12-14]. The reason for this is still not well investigated; however, the higher incidence of $\mathrm{CP}$ in males is probably related to a greater biological vulnerability in terms of cerebral structure, hormone protective role, and genetic differences. Some studies have shown the protective influence of female hormones from brain damage $[15,16]$. The mechanisms for the difference in the vulnerability of the brain of male and female foetus is not well understood but the physiological differences may play a role in the differential vulnerability other study showed that even in traumatic brain injury cases also, progesterone plays neuro protective role against brain damage [17]. 


\section{CONCLUSIONS}

Males developed CP more than females; spastic quadriplegia is the most common type of $\mathrm{CP}$, as proven by other national and international studies. birth asphyxia, Prematurity and neonatal meningitis are found to be the important risk factors for $\mathrm{CP}$ in our study which can be avoided by improving maternal and pediatric health services.

However, current study is limited to lesser group of 108 cerebral palsy children; more research with large number of cerebral palsy affected children is needed before coming to a conclusion about the incidence of cerebral palsy in area of study.

\section{REFERENCES}

1. Shevell, M. I., \& Bodensteiner, J. B. (2004, March). Cerebral palsy: defining the problem. In Seminars in pediatric neurology (Vol. 11, No. 1, pp. 2-4). WB Saunders.

2. Mutch, L., Alberman, E., Hagberg, B., Kodama, K., \& Perat, M. V. (1992). Cerebral palsy epidemiology: where are we now and where are we going?. Developmental Medicine \& Child Neurology, 34(6), 547-551.

3. Wu, Y. W., \& Colford Jr, J. M. (2000). Chorioamnionitis as a risk factor for cerebral palsy: a meta-analysis. Jama, 284(11), 1417-1424.

4. Wu, Y. W., Escobar, G. J., Grether, J. K., Croen, L. A., Greene, J. D., \& Newman, T. B. (2003). Chorioamnionitis and cerebral palsy in term and near-term infants. Jama, 290(20), 2677-2684.

5. Stanley, F., Blair, E., \& Alberman, E. (2000). How common are the cerebral palsies. Cerebral Palsies: Epidemiology and Causal Pathways Clinics in Developmental Medicine, 39.

6. Singhi, P. D., Ray, M., \& Suri, G. (2002). Clinical spectrum of cerebral palsy in North India-an analysis of 1000 cases. Journal of tropical pediatrics, 48(3), 162-166.

7. Aneja, S. (2004). Evaluation of a child with cerebral palsy. The Indian Journal of Pediatrics, 71(7), 627-634.
8. Malik, B. A., Zafar, S., Razzaq, A., Butt, M. A., Khan, M. S., \& Mughal, S. (2007). Frequently associated problems of cerebral palsy. Annals of Punjab Medical College (APMC), 1(2), 14-18.

9. Soleimani, F., Zaheri, F., \& Abdi, F. (2014). Longterm neurodevelopmental outcomes after preterm birth. Iranian Red Crescent Medical Journal, 16(6).

10. McMichael, G., Girirajan, S., Moreno-De-Luca, A., Gecz, J., Shard, C., Nguyen, L. S., ... \& MacLennan, A. (2014). Rare copy number variation in cerebral palsy. European Journal of Human Genetics, 22(1), 40-45.

11. Segel, R., Ben-Pazi, H., Zeligson, S., FatalValevski, A., Aran, A., Gross-Tsur, V., ... \& LevyLahad, E. (2015). Copy number variations in cryptogenic cerebral palsy. Neurology, 84(16), 1660-1668.

12. Johnson, A. (2002). Prevalence and characteristics of children with cerebral palsy in Europe. Developmental medicine and child neurology, 44(9), 633-640.

13. Das, N., Bezboruah, G., \& Das, I. (2016). Study on the Clinical Profile of Patients with Cerebral Palsy. International Organization of Scientific Research Journal of Dental and Medical Sciences, 15(07), 54-58.

14. Romeo, D. M., Sini, F., Brogna, C., Albamonte, E., Ricci, D., \& Mercuri, E. (2016). Sex differences in cerebral palsy on neuromotor outcome: a critical review. Developmental Medicine \& Child Neurology, 58(8), 809-813.

15. Vasileiadis, G. T., Thompson, R. T., Han, V. K., \& Gelman, N. (2009). Females follow a more "compact" early human brain development model than males. A case-control study of preterm neonates. Pediatric research, 66(5), 551-554.

16. Stanley, F. J., Blair, E., \& Alberman, E. (2000). Cerebral palsies: epidemiology and causal pathways (No. 151). Cambridge University Press.

17. Hoffman, G. E., Merchenthaler, I., \& Zup, S. L. (2006). Neuroprotection by ovarian hormones in animal models of neurological disease. Endocrine, 29(2), 217-231. 